\title{
The British Association at Leicester
}

$T^{\mathrm{H}}$ HE full programme of the British Association meeting to be held at Leicester on September 6-13, will be shortly in the hands of members. It shows no less promise of interest than usual, whether interest be judged from the point of view of the scientific worker or of the public. Certainly topics of wide current importance are not neglected by the Association in these days; no less certainly the "general interest in science and its applications" which the Association, by its own claim, "seeks to promote", is increasing, if slowly.

In his inaugural address the president, Sir Frederick Gowland Hopkins, president of the Royal Society, will discuss some chemical aspects of life. Dr. J. Gray's address to Section D (Zoo$\operatorname{logy}$, on the mechanical view of life, cannot but provide a notable complement to that of Sir Frederick Hopkins. Among other sectional addresses of the widest appeal, examples are Sir Gilbert Walker's to Section A (Mathematical and Physical Sciences), on seasonal weather and its prediction; Prof. J. H. Jones's to Section F (Economics) on the gold standard, and Mr. J. L. Holland's to Section $\mathrm{L}$ (Education) on the development of the national system of education.

The various sections of the Association are, by tradition, autonomous under their respective committees, and it is not many years since it was urged in these columns that the Association should take steps to co-ordinate its sectional work. Co-ordination, in recent years, has been fostered, mainly through the institution, at the instance of the late general treasurer, Dr. E. H. Griffiths, of the joint meetings of organising sectional committees held in January. At the same time, there has been a strong movement toward the arrangement of sectional programmes under prescribed broad headings. Several sections now formulate the whole or almost the whole of their programmes on this principle. Thus it comes about that at Leicester, Section L (Education) is to hear groups of communications and discussions on training for business and administration, the cultural value of science in adult education, and other such large topics; Section M (Agriculture) will similarly deal with milk production and distribution in relation to nutrition and disease, with land drainage, and with sociological aspects of agriculture ; and there are plenty of other examples.

Some of the sections, notably on the biological side (as is natural) adhere more nearly to the type of programme in which the majority of speakers deal with minutiæ in their own special fields; but such sections do not nowadays overlook their wider contacts, and this year we find Section D (Zoology), I (Physiology) and K (Botany) staging a joint discussion on genetics. The sphere of Section A (Mathematical and Physical Sciences) is so extensive that it must find room for both types of communication; among much that might be cited there is space here to refer only to the discussion on atomic transmutation, to be opened by Lord Rutherford, and that on the expanding universe to be opened by Sir Arthur Eddington.

The traditional type of evening discourse, with experiments, has found its way back into recent programmes, and this year Prof. J. F. Thorpe is to speak upon, and demonstrate the work of, the Safety in Mines Research Board, the Secretary for Mines being expected to be present. As for the other evening discourse, the social implications of the advance of science were brought to the notice of the Association last year in no uncertain terms, and this year Sir Josiah Stamp is to address the members under a properly provocative title, "Must Science ruin Economic Progress?" The preliminary programme of the Department of Industrial Co-operation of Section $\mathrm{F}$ (Economics) well illustrates the interest of the Association in economic, industrial and social problems. The opening discussion of the Department on September 7 deals with "Organisation as a Technical Problem." Dr. E. F. Armstrong will occupy the chair and Major L. Urwick will open the discussion. The programme of visits to industrial establishments includes a representative number of important firms such as the Dunlop Rubber Co. and Messrs. Boots Ltd., Nottingham.

The new practice instituted last year, of compiling and issuing in advance a scientific survey of the place of meeting and its neighbourhood, on a definite plan, in lieu of the former unsystematised local handbooks, will be continued this year, and, it is to be hoped, in future. The scientific survey of Leicester and district, compiled under the editorship of Dr. Bryan, vice-principal of University College, Leicester, indicates the wide interests for which Leicester is a centre, and further evidence of this appears in the extensive series of general and sectional excursions which has been arranged. A geological excursion to the Lower Palæozoic Rocks of the Welsh borderland has been arranged to take place before the meeting, terminating at Leicester on September 6 .

The only word of regret to be spoken at this moment is that the intimations of attendance received from visiting members are as yet substantially sub-normal in number. Any falling off in their support must react unfavourably upon the Association's grants in aid of research. The Association may be the more grateful to its energetic local committee in Leicester for the efforts the members are making, through a special sub-committee, to assure an ample local membership. To attract such local support is one of the first objects of the Association, and one which its permanent organisation is least able to achieve unaided. 